\title{
PENGARUH DENSITAS URANIUM TERHADAP UMUR DAN BURN UP BAHAN BAKAR NUKLIR DI DALAM REAKTOR RSG-GAS DITINJAU DARI ASPEK NEUTRONIK
}

\author{
Saga Octadamailah, Supardjo \\ Pusat Teknologi Bahan Bakar Nuklir - BATAN \\ Kawasan Puspiptek, Serpong, Tangerang Selatan, 15314 \\ e-mail : saga_octa@batan.go.id
}

(Naskah diterima: 08-06-2017, Naskah direvisi: 21-06-2017, Naskah disetujui: 12-07-2017)

\begin{abstract}
ABSTRAK
PENGARUH DENSITAS URANIUM TERHADAP UMUR DAN BURN UP BAHAN BAKAR NUKLIR DI DALAM REAKTOR RSG-GAS DITINJAU DARI ASPEK NEUTRONIK. Reaktor Serba Guna G.A. Siwabessy (RSG-GAS) Serpong merupakan reaktor nuklir tipe Material Testing Reactor (MTR). Reaktor ini awalnya dioperasikan menggunakan bahan bakar dispersi $\mathrm{U}_{3} \mathrm{O}_{8} / \mathrm{Al}$ pengkayaan uranium $19,75 \%{ }^{235} \mathrm{U}$ dengan densitas uranium 2,96 $\mathrm{gU} / \mathrm{cm}^{3}$. Bahan bakar $\mathrm{U}_{3} \mathrm{Si}_{2} / \mathrm{Al}$ densitas 2,96 $\mathrm{gU} / \mathrm{cm}^{3}$ telah berhasil diproduksi dan digunakan sebagai bahan bakar RSG-GAS menggantikan bahan bakar $\mathrm{U}_{3} \mathrm{O}_{8} / \mathrm{Al}$, sedangkan penelitian bahan bakar berbasis UMo/Al dengan densitas $7 \mathrm{gU} / \mathrm{cm}^{3}$ juga telah diperoleh dalam bentuk pelat mini. Penelitian tentang bahan bakar densitas tinggi masih berfokus pada proses pabrikasi, sedangkan perhitungan tentang umur atau masa pakai (lifetime) dan korelasinya dengan burn up bahan bakar belum banyak dilakukan. Berkaitan dengan hal tersebut, pada penelitian ini dilakukan perhitungan umur bahan bakar dan korelasinya terhadap burn up menggunakan pasangan program ORIGEN dan MCNP. Program ORIGEN digunakan untuk mensimulasikan proses waktu iradiasi, sehingga diperoleh data produk fisi dan uranium sisa ${ }^{235} \mathrm{U}$ tidak mengalami reaksi fisi). Sementara itu, program MCNP digunakan untuk menghitung kritikalitas di dalam teras reaktor. Waktu iradiasi digunakan untuk perhitungan umur bahan bakar, sedangkan kritikalitas digunakan untuk mengetahui burn up maksimal untuk bahan bakar $\mathrm{U}_{3} \mathrm{Si}_{2} / \mathrm{Al}$ dan UMo/Al. Hasil perhitungan menunjukkan bahwa peningkatan densitas uranium berdampak kepada bertambahnya lama iradiasi di dalam reaktor dan burn up bahan bakar. Waktu yang dibutuhkan untuk mencapai burn up $56 \%$ masing masing bahan bakar $\mathrm{U}_{3} \mathrm{O}_{8} / \mathrm{Al} ; \mathrm{U}_{3} \mathrm{Si}_{2} / \mathrm{Al}$, dan U-7Mo/Al selama 188 hari, 292 hari, dan 420 hari. Peningkatan densitas uranium menyebabkan bahan bakar $\mathrm{U}_{3} \mathrm{O}_{8} / \mathrm{Al}$ mampu mencapai burn up $56 \%$, sedangkan $\mathrm{U}_{3} \mathrm{Si}_{2} / \mathrm{Al}$ dan U-7Mo/Al dapat mencapai nilai burn up sebesar $68,97 \%$ dan $76,76 \%$. Meningkatnya umur (lifetime) dan burn up bahan bakar berdampak kepada meningkatkan efisiensi bahan bakar di dalam reaktor.
\end{abstract}

Kata kunci: densitas uranium, umur bahan bakar, burn up, reaktor riset, neutronik. 


\section{ABSTRACT}

EFFECT OF URANIUM DENSITY ON NUCLEAR FUEL LIFE TIME AND BURN UP IN RSGGAS REACTOR FROM A NEUTRONIC POINT OF VIEW. Material Testing Reactor (MTR) is a research reactor with characteristics: small power, high thermal neutron flux and short life time fuel. Reaktor Serba Guna G.A. Siwabessy (RSG-GAS) located in Serpong is an MTR type reactor initially operated with dispersion fuel of $\mathrm{U}_{3} \mathrm{O}_{8} / \mathrm{Al}$ with uranium enrichment of $19.75 \%{ }^{235} \mathrm{U}$ and uranium density of $2.96 \mathrm{gU} / \mathrm{cm}^{3}$. In an effort to increase the life time of nuclear fuel, BATAN has done researches on high density uranium fuel starting from $U_{3} S_{2} / A l$ fule and continued with UMo based fuel in line with investigations performed by worldwide researchers in the field of research reactors. Fuel of $U_{3} S_{2} / A l$ with a density of $2.96 \mathrm{gU} / \mathrm{cm}^{3}$ has been successfully manufactured and utilized as fuel for RSG-GAS to subtitute the $\mathrm{U}_{3} \mathrm{O}_{8} / A$ l fuel. Post irradiation examination has also been done for $U_{3} S_{2} / A l$ with a density of $4.8 \mathrm{gU} / \mathrm{cm}^{3}$ up to a burn up of $60 \%$, while research on UMo with $7 \mathrm{gU} / \mathrm{cm}^{3}$ density has been progressing into mini plate fabrication. Research on high density fuel has been focused on fabrication process, while little has been done on life time calculation or utilization period. Therefore, this research has performed a calculation on nuclear fuel life time using a paired program of ORIGEN and MCNP. The calculation results show that an increase in uranium density will extend the life time of fuel exponentially. The longest life time is achieved by UMo type, which extends to 651 days, and this relates to a life time extension of 219 days if the RSG-GAS is operated with UMo fuel.

Keywords: uranium density, fuel life, burn up, research reactor, neutronic. 


\section{PENDAHULUAN}

Pengembangan teknologi nuklir di dunia tidak bisa dipisahkan dari keberadaan reaktor nuklir baik reaktor riset yang digunakan untuk penelitian dan produksi radioisotop maupun reaktor daya untuk menghasilkan energi listrik. Reaktor riset pada umumnya didesain dengan daya rendah dan menggunakan bahan bakar nuklir dalam bentuk uranium oksida maupun paduan uranium dengan pengkayaan uranium > 19,75 \% ${ }^{235} \mathrm{U}$, sedangkan reaktor daya didesain pada daya tinggi dengan pengkayaan uranium $<5 \%{ }^{235} \mathrm{U}$ atau bahkan menggunakan uranium alam[1,2].

Badan Tenaga Nuklir Nasional (BATAN) merupakan lembaga penelitian nuklir di Indonesia, saat ini memiliki tiga buah reaktor riset yang digunakan untuk penelitian dan produksi radioisotop. Reaktor TRIGA 2000 merupakan reaktor pertama yang di bangun di Bandung, kemudian reaktor Kartini (jenis TRIGA) dengan daya 250 Watt dibangun di Yogyakarta dan Reaktor Serba Guna G.A Siwabessy (RSGGAS) dengan daya $30 \mathrm{MW}$ di Serpong. Tipe RSG-GAS adalah material testing reactor (MTR), memiliki fluks neutron termal sebesar $2 \times 10^{14}$ neutron $/ \mathrm{cm}^{2} s[3]$, sehingga satu hari pengujian di dalam RSG-GAS setara dengan 3 bulan di reaktor daya atau Pembangkit Listrik Tenaga Nuklir (PLTN). Hal ini disebabkan karena fluks neutron yang dihasilkan di dalam teras reaktor seratus kali lebih banyak bila dibandingkan dengan reaktor daya, walaupun daya RSGGAS relatif kecil.

Reaktor riset bermacam-macam sehingga jenis dan bentuk bahan bakar juga berbeda beda. Fluks neutron tinggi dengan daya kecil menandakan bahwa hanya sedikit neutron yang berinteraksi dengan bahan bakar. Volume bahan bakar yang terbatas menyebabkan umur bahan bakar di dalam reaktor relatif lebih pendek jika dibandingkan dengan bahan bakar untuk PLTN. Untuk memperpanjang umur bahan bakar reaktor riset, maka dikembangkanlah bahan bakar densitas tinggi dengan muatan uranium lebih banyak[2].

Penelitian bahan bakar reaktor riset dengan densitas uranium tinggi telah menarik ilmuwan di dunia dalam rangka mendapatkan material baru yang memiliki densitas tinggi. Beberapa material telah diteliti, dan material baru yang sesuai sebagai kandidat bahan bakar nuklir adalah paduan uranium. Senyawa $\mathrm{UAl}_{\mathrm{x}}$ adalah merupakan bahan bakar reaktor riset pertama yang digunakan dengan uranium pengkayaan ${ }^{235} \mathrm{U}$ tinggi $\left(>90 \%{ }^{235} \mathrm{U}\right)$. Penggunaan bahan bakar dengan uranium pengkayaan tinggi beresiko disalahgunakan untuk dimanfaatkan dalam persenjataan nuklir, sehingga dikembangkan bahan bakar baru menggunakan uranium dengan pengkayaan rendah $\left(<20 \%{ }^{235} \mathrm{U}\right)[2]$.

Penelitian yang dilakukan oleh Saliba dkk[4] menggunakan berbagai macam material sebagai alternatif bahan bakar telah menemukan bahwa densitas uranium optimal dari masing-masing material ditunjukkan pada Gambar 1. Dari Gambar 1 dapat diketahui bahwa dengan menggunakan paduan berbasis UMo sebagai bahan bakar, dihasilkan densitas uranium yang jauh lebih besar dibandingkan dengan material lainnya pada volume bahan bakar yang sama[4].

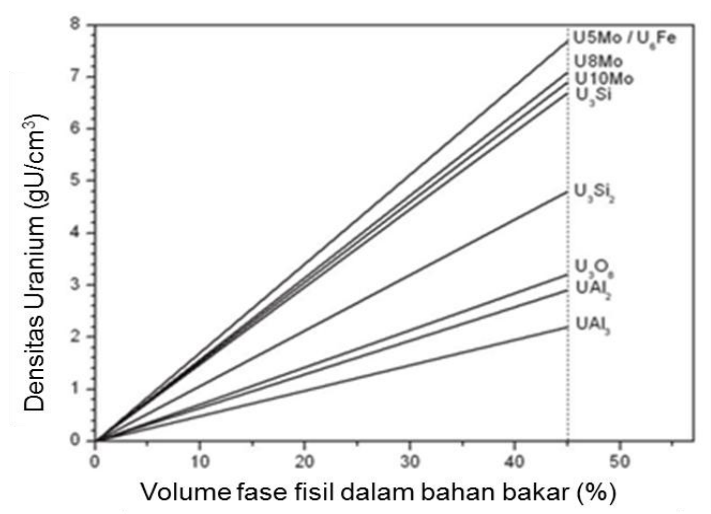

Gambar 1. Konsentrasi fase terdispersi bahan fisil terhadap densitas uranium[4]. 
Pusat Teknologi Bahan Bakar (PTBBN), BATAN memiliki tugas penelitian pengembangan bahan bakar nuklir untuk reaktor riset maupun daya serta material komponen strukturnya. Hasil penelitian bahan bakar dispersi $\mathrm{U}_{3} \mathrm{Si}_{2} / \mathrm{Al}$ tipe pelat telah berhasil ditingkatkan ke skala produksi untuk bahan bakar RSG-GAS. Penelitian bahan bakar dispersi berbasis UMo merupakan penelitian lebih lanjut sesuai yang dilakukan di dunia dalam rangka mendapatkan bahan bakar baru yang memiliki densitas uranium tinggi. Beberapa pelat elemen bakar/PEB U7Mo/Al dan U-7Mo-M/Al ( $\mathrm{M}=\mathrm{Si}, \mathrm{Ti}, \mathrm{Zr}$ ) dalam bentuk mini telah dibuat dan dilakukan karakterisasi ${ }^{[5,7]}$, sedangkan untuk mengetahui pengaruh kenaikan densitas uranium terhadap umur bahan bakar di dalam reaktor perlu diprediksi melalui perhitungan.

Beberapa peneliti telah melakukan perhitungan umur bahan bakar. Salah satu metode yang digunakan untuk menentukan umur bahan bakar adalah dengan langsung menggunakannya di dalam teras reaktor sehingga diperoleh burn up sebesar 654,0094 MWD per siklus[8]. Metode ini hanya dapat digunakan untuk bahan bakar operasional reaktor, yang sampai saat ini masih menggunakan bahan bakar dengan densitas uranium 2,96 $\mathrm{gU} / \mathrm{cm}^{3}$. Peneliti lain mendapatkan bahwa umur siklus 21,8 hari (654 MWD) untuk densitas uranium 2,96 $\mathrm{gU} / \mathrm{cm}^{3}$ dan 40 hari (1200 MWD) untuk densitas uranium $4,8 \mathrm{gU} / \mathrm{cm}^{3}[9]$. Penelitian dilanjutkan dengan menggunakan massa uranium dalam bahan bakar berturut-turut sebesar $360 \mathrm{~g}$ (untuk densitas $4,26 \mathrm{gU} / \mathrm{cm}^{3}$ ); $390 \mathrm{~g}\left(4,62 \mathrm{gU} / \mathrm{cm}^{3}\right)$ dan $450 \mathrm{~g}(5,33$ $\mathrm{gU} / \mathrm{cm}^{3}$ ), dimana dari hasil perhitungan diperoleh nilai burn up sebesar 1100 MWD, 1400 MWD dan 1900 MDW per siklus[10].

Umur siklus adalah waktu tinggal bahan bakar pada posisi tertentu. Dengan batasan burn up bahan bakar RSG-GAS sebesar $56 \%$ untuk jenis bahan bakar $\mathrm{U}_{3} \mathrm{Si}_{2}$ dengan densitas uranium $2,96 \mathrm{gU} / \mathrm{cm}^{3}$ dan burn up per siklus sebesar $7 \%$, maka akan terjadi 8 kali perpindahan posisi bahan bakar. Pemindahan posisi bahan bakar ini bertujuan untuk mencapai teras setimbang (distribusi daya di teras reaktor merata). Setelah mencapai burn up $56 \%$, bahan bakar dikeluarkan dari teras reaktor. Waktu tinggal di dalam teras reaktor inilah yang dimaksud pada penelitian ini sebagai umur bahan bakar.

Umur bahan bakar dapat dilihat dari beberapa aspek, diantaranya mekanik dan neutronik. Aspek mekanik salah satunya berkaitan dengan ketahanan bahan bakar terhadap tekanan sebagian produk fisi yang berupa gas. Semakin tinggi burn up, semakin banyak produk fisi yang dihasilkan. Umur bahan bakar ditentukan dari tekanan maksimal yang dapat ditahan oleh bahan bakar. Aspek ini dapat diatasi dengan membatasi volume fase fisil dalam bahan bakar seperti yang ditunjukkan pada Gambar 1, dimana volume fase fisil yang digunakan pada penelitian tersebut maksimal sebesar $45 \%$.

Aspek lain yang berkaitan erat dengan umur bahan bakar secara langsung adalah aspek neutronik, yang akan dibahas pada makalah ini. Aspek neutronik adalah aspek yang menentukan umur bahan bakar berdasarkan jumlah energi yang dapat dihasilkan. Berbeda dengan bahan bakar fosil yang bahan bakarnya bisa terbakar habis, pada bahan bakar nuklir tidak demikian.

Energi yang dihasilkan dari bahan bakar nuklir adalah energi hasil reaksi fisi. Reaksi fisi terjadi karena adanya neutron yang menumbuk inti atom bahan fisil ${ }^{235} \mathrm{U}$ atau ${ }^{238} U$, sehingga energi yang dihasilkan sangat bergantung pada massa ${ }^{235} \mathrm{U}$ dan populasi neutron. Perbandingan populasi neutron dari siklus neutron yang satu dengan siklus yang lain disebut kritikalitas (k). Reaktor dalam kondisi kritis apabila mencapai $k=1$, yang berarti populasi neutron stabil dari waktu ke waktu. Nilai $k$ bergantung pada jumlah atom unsur absorber dan fisil yang mana keduanya ada 
pada unsur uranium, yaitu ${ }^{238} \mathrm{U}$ sebagai absorber dan ${ }^{235} \mathrm{U}$ sebagai fisil. Pada saat ${ }^{235} \mathrm{U}$ melakukan reaksi fisi dan terbelah, maka jumlah ${ }^{235} \mathrm{U}$ pada bahan bakar akan semakin berkurang. Pada saat ${ }^{235} \mathrm{U}$ sudah banyak yang terbakar, maka jumlah neutron hasil reaksi fisi tidak dapat mengimbangi jumlah neutron yang diserap oleh ${ }^{238} \mathrm{U}$. Populasi neutron semakin berkurang $(k<1)$ dan reaksi fisi di dalam reactor tidak bisa berlanjut. Hal inilah yang menyebabkan bahan bakar nuklir khususnya ${ }^{235 U}$ tidak dapat dibakar habis.

Sementara itu, nilai burn up bahan bakar untuk jenis dan densitas tertentu dapat digunakan sebagai acuan perhitungan umur bahan bakar. Hubungan antara peningkatan densitas uranium dengan umur bahan bakar dihitung menggunakan pasangan aplikasi Oak Ridge Isotope Generation (ORIGEN) dan Monte Carlo $n$ Partikel (MCNP).

\section{a. Penggunaan Aplikasi ORIGEN}

ORIGEN adalah sebuah kode program untuk menghitung pembentukan, peluruhan, dan proses dari material radioaktif[11]. Program ORIGEN banyak digunakan untuk menghitung jumlah uranium fisil yang terbakar (burn up) dan material hasil proses operasional reaktor. Perhitungan burn up menggunakan program ORIGEN dilakukan dengan dua metode yaitu menggunakan acuan daya dan menggunakan acuan fluks neutron. Acuan daya lebih banyak digunakan karena perhitungan hanya berdasarkan jumlah bahan bakar, sedangkan jika menggunakan acuan fluks neutron sangat bergantung pada dimensi bahan bakar maupun dimensi teras reaktor, dimana bentuk bahan bakar dan teras yang bisa dimodelkan di ORIGEN sangat terbatas.

\section{b. Penggunaan Aplikasi MCNP}

Penggunaan metode Monte Carlo banyak digunakan pada proses yang bersifat probabilistik, salah satunya digunakan pada perhitungan kritikalitas reaktor. Metode Monte Carlo dianggap sebagai metode yang paling mendekati kondisi sebenarnya. MCNP merupakan salah satu aplikasi yang menggunakan metode Monte Carlo dan transport neutron sebagai dasar perhitungannya, sehingga hasil perhitungan yang diperoleh sangat akurat[12]. MCNP banyak digunakan untuk menghitung kritikalitas efektif teras reaktor $\left(k_{\text {eff }}\right)$.

\section{METODOLOGI}

Perhitungan umur bahan bakar nuklir di dalam reaktor dilakukan melalui tiga tahap, yaitu tahap pertama adalah perhitungan umur bahan bakar pada burn up $56 \%$, tahap kedua adalah perhitungan burn up maksimal bahan bakar dan tahap ketiga adalah tahap perhitungan umur bahan bakar pada burn up maksimal. Daya reaktor yang dipakai dalam perhitungan ini adalah $30 \mathrm{MW}$ (daya maksimal RSG-GAS). Pengkayaan uranium yang digunakan adalah 19,89\%. Jenis bahan bakar yang digunakan dalam perhitungan adalah $\mathrm{U}_{3} \mathrm{O}_{8} / \mathrm{Al}, \mathrm{U}_{3} \mathrm{Si}_{2} / \mathrm{Al}$ dan UMo/Al dengan densitas uranium masingmasing sebesar $2,96 \mathrm{gU} / \mathrm{cm}^{3}, 4,8 \mathrm{gU} / \mathrm{cm}^{3}$ dan $7,0 \mathrm{gU} / \mathrm{cm}^{3}$. Adapun rincian perhitungan pada tahap pertama seperti yang ditunjukkan pada Gambar 2.

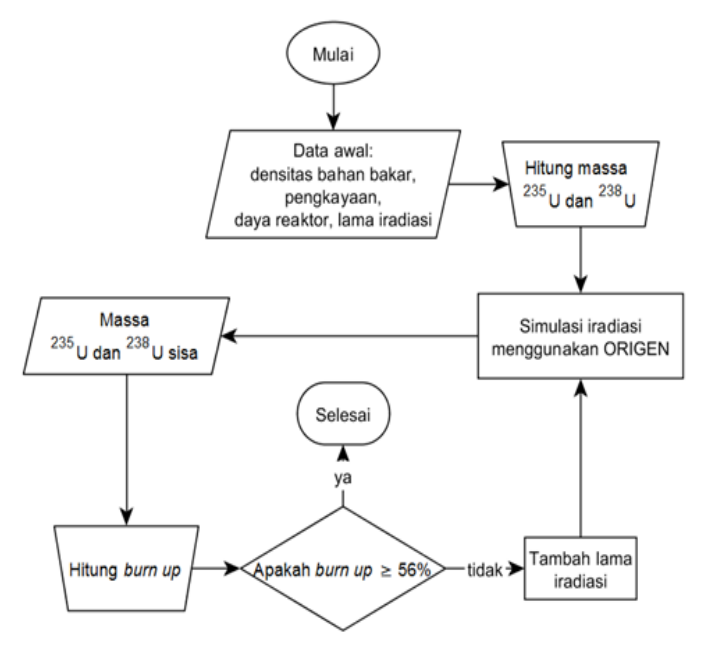

Gambar 2. Diagram alir model perhitungan umur bahan bakar pada burn up $56 \%$ 
Langkah pada Gambar 2 menunjukkan tahap perhitungan umur bahan bakar dilakukan untuk semua jenis bahan bakar (3 jenis). Tujuannya adalah untuk membandingkan umur dari masingmasing bahan bakar. Selain itu, karena pada saat ini RSG-GAS menggunakan bahan bakar dengan densitas uranium 2,96 gU/ $/ \mathrm{cm}^{3}$ dan densitas tersebut diwakili oleh bahan bakar $\mathrm{U}_{3} \mathrm{O}_{8} / \mathrm{Al}$, maka tahap ini juga bertujuan untuk mengetahui apakah pemodelan yang dilakukan sudah sesuai dengan yang ada di lapangan atau belum.

Umur bahan bakar diperoleh dari lama iradiasi (1 siklus sekitar 22 hari), sedangkan lama iradiasi merupakan data input pada program ORIGEN. Sementara itu, untuk mendapatkan burn up $56 \%$ harus dilakukan iterasi (pengulangan) dengan menambahkan lama iradiasi secara bertahap. Proses iterasi dilakukan sebanyak 95 kali dengan variasi lama iradiasi kelipatan 2 hari untuk bahan bakar $\mathrm{U}_{3} \mathrm{O}_{8} / \mathrm{Al}$, sedangkan untuk bahan bakar $\mathrm{U}_{3} \mathrm{Si}_{2} / \mathrm{Al}$ dan UMo/AI, dilakukan iterasi masing-masing 100 kali dengan variasi lama iradiasi kelipatan 4 hari dan 7 hari.

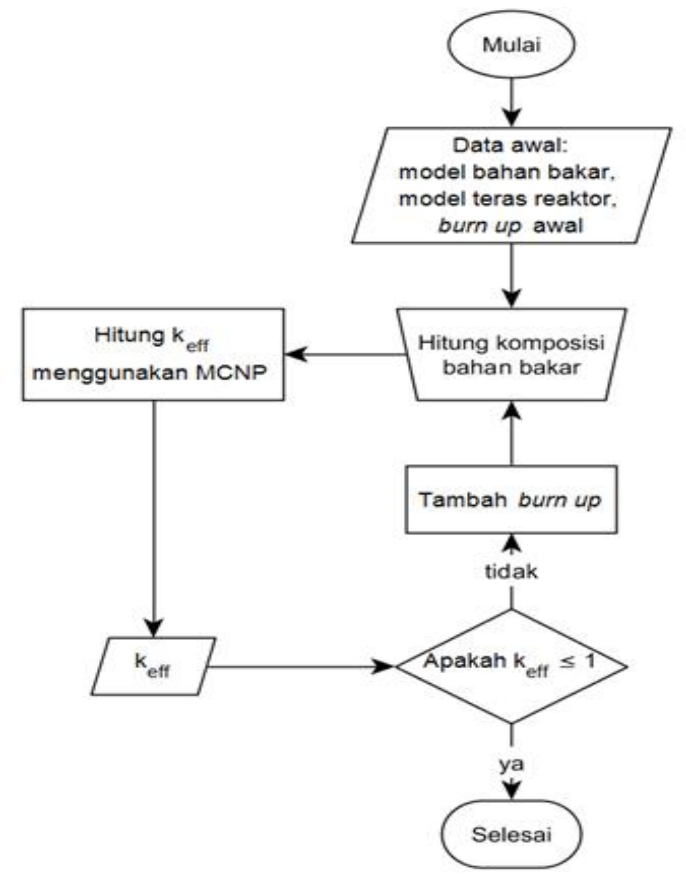

Gambar 3. Diagram alir model penentuan burn up maksimal
Adapun rincian perhitungan burn up maksimal pada tahap kedua ditunjukkan pada Gambar 3. Langkah awal yang dilakukan pada tahap kedua adalah memodelkan bahan bakar dan teras reaktor, dimana hasil pemodelan tersebut merupakan data awal untuk menghitung kritikalitas.

Model bahan bakar dan teras reaktor dimasukkan ke dalam program MCNP. Burn up maksimal bahan bakar $\mathrm{U}_{3} \mathrm{O}_{8} / \mathrm{Al}$ dengan densitas $2,96 \mathrm{gU} / \mathrm{cm}^{3}$ sudah diketahui dari referensi sebesar $56 \%{ }^{[8]}$, sehingga pada tahap ini bahan bakar $\mathrm{U}_{3} \mathrm{O}_{8} / \mathrm{Al}$ dijadikan sebagai acuan model bahan bakar untuk pemodelan bahan bakar jenis $\mathrm{U}_{3} \mathrm{Si}_{2} / \mathrm{Al}$ dan UMo/Al.

Dimensi bahan bakar (volume dan tebal) dibuat sama dengan desain RSGGAS, namun teras reaktor dimodelkan tanpa elemen kendali. Hal ini dibuat karena tanpa elemen kendali, bahan bakar dinyatakan telah mencapai burn up maksimal atau apabila tidak menghasilkan reaktivitas positif atau hasil perhitungan $k_{\text {eff }}=1$. Hal ini digunakan sebagai dasar pemodelan, sehingga model teras dapat divariasikan baik jumlah bahan bakar maupun dimensi teras sehingga mencapai $\mathrm{k}_{\text {eff }}=1$.

Desain bahan bakar ditunjukkan pada Gambar 4, dimana tiap elemen bakar terdapat 21 buah pelat elemen bakar (PEB).

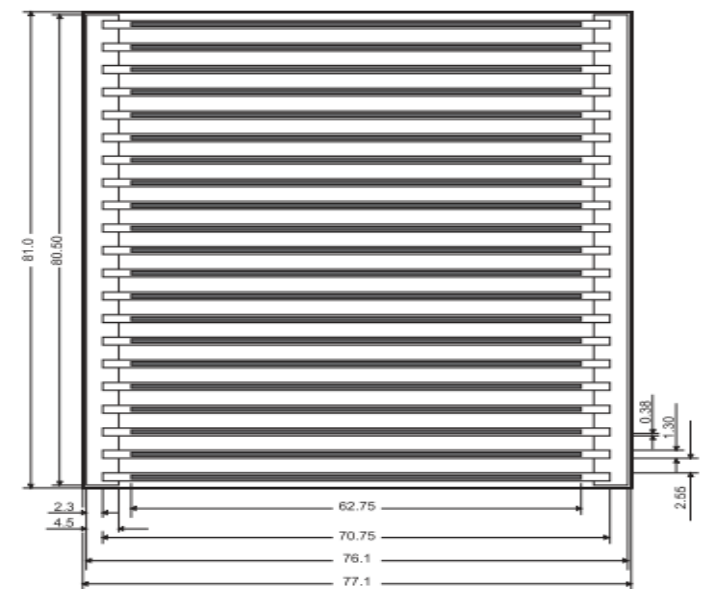

Gambar 4. Elemen bakar standar RSGGAS[13] 
Pemodelan bahan bakar dan teras reaktor diperoleh menggunakan acuan bahan bakar $\mathrm{U}_{3} \mathrm{O}_{8} / \mathrm{Al}$ dengan burn up $56 \%$, selanjutnya dilakukan perhitungan $\mathrm{k}_{\text {eff }}$ untuk jenis bahan bakar yang lain, yaitu $\mathrm{U}_{3} \mathrm{Si}_{2} / \mathrm{Al}$ dan UMo/Al. Perhitungan $\mathrm{k}_{\text {eff }}$ dimulai dengan burn up $7 \%$, kemudian diiterasi dengan menaikkan nilai burn up antara 5-7\% sampai diperoleh $\mathrm{k}_{\text {eff }} \leq 1$. Pada saat $\mathrm{k}_{\text {eff }}=1$ inilah dicapai burn up maksimal untuk bahan bakar $\mathrm{U}_{3} \mathrm{Si}_{2} / \mathrm{Al}$ dan UMo/Al.

Apabila bahan bakar $\mathrm{U}_{3} \mathrm{O}_{8} / \mathrm{Al}$ diiradiasi sampai mencapai burn up 56\%, maka diperoleh $44 \%$ bahan fisil ${ }^{235} \mathrm{U}$ yang tersisa. Bila bahan bakar UMo/Al diiradiasi sampai burn up $56 \%$, maka dengan densitas uranium akan diperoleh 2 kali lebih tinggi dari $\mathrm{U}_{3} \mathrm{O}_{8} / \mathrm{Al}$ dan akan menghasilkan ${ }^{235} \mathrm{U}$ sisa setara dengan bahan bakar $\mathrm{U}_{3} \mathrm{O}_{8} / \mathrm{Al}$ yang belum teriradiasi.

Dengan dasar tersebut maka pada tahap terakhir dilakukan perhitungan umur bahan bakar menggunakan burn up yang diperoleh dari perhitungan MCNP. Langkah yang dilakukan pada tahap ketiga ini hampir sama dengan langkah pada tahap pertama, namun burn up yang digunakan bukan $56 \%$, melainkan burn up hasil perhitungan MCNP pada tahap kedua. Adapun rincian langkah yang dilakukan pada tahap ketiga seperti yang ditunjukkan pada Gambar 5.

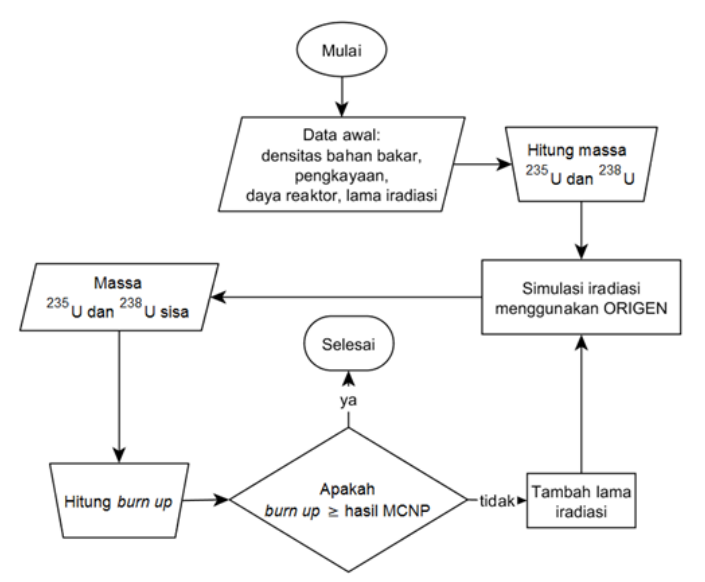

Gambar 5. Diagram alir metode perhitungan umur bahan bakar pada burn up maksimal.

Perhitungan yang dilakukan pada tahap ketiga ini hanya bahan bakar $\mathrm{U}_{3} \mathrm{Si}_{2} / \mathrm{Al}$ dan UMo/Al, sedangkan bahan bakar $\mathrm{U}_{3} \mathrm{O}_{8} / \mathrm{Al}$ sudah diketahui umurnya dari tahap model perhutungan tahap pertama.

\section{HASIL DAN PEMBAHASAN}

Hasil perhitungan tahap awal diperoleh massa uranium yaitu ${ }^{235} \mathrm{U}$ dan ${ }^{238} \mathrm{U}$ dalam Elemen Bakar seperti ditunjukkan pada Tabel 1.

Tabel 1. Perhitungan massa ${ }^{235} \mathrm{U}$ dan ${ }^{238} \mathrm{U}$ dalam Elemen Bakar

\begin{tabular}{|c|c|c|c|c|c|c|c|}
\hline $\begin{array}{c}\text { Bahan } \\
\text { bakar }\end{array}$ & $\begin{array}{c}\text { Densitas } \\
\text { uranium } \\
\left(\mathrm{gU} / \mathrm{cm}^{3}\right)\end{array}$ & $\begin{array}{c}\text { Volume } \\
\text { IEB } \\
\left(\mathrm{cm}^{3}\right)\end{array}$ & $\begin{array}{c}\text { Pengkayaan } \\
(\%)\end{array}$ & $\begin{array}{c}\text { Massa } \\
235 \mathrm{U} \\
(\mathrm{g})\end{array}$ & $\begin{array}{c}\text { Jumlah } \\
\mathrm{IEB} / \mathrm{EB}\end{array}$ & $\begin{array}{c}\text { Massa } \\
235 \mathrm{U} / \mathrm{EB} \\
(\mathrm{g})\end{array}$ & $\begin{array}{c}\text { Massa } \\
238 / \mathrm{EB}, \\
(\mathrm{g})\end{array}$ \\
\hline $\mathrm{U}_{3} \mathrm{O}_{8} / \mathrm{Al}$ & 3,11 & 19,23 & 19,89 & 11,90 & 21 & 249,80 & 1006,11 \\
\hline $\mathrm{U}_{3} \mathrm{Si}_{2} / \mathrm{Al}$ & 4,80 & 19,23 & 19,89 & 18,36 & 21 & 385,54 & 1552,82 \\
\hline $\mathrm{U}-7 \mathrm{Mo} / \mathrm{Al}$ & 7,00 & 19,23 & 19,89 & 26,77 & 21 & 562,25 & 2264,55 \\
\hline
\end{tabular}

Hasil perhitungan pada Tabel 1 digunakan sebagai data masukan untuk perhitungan neutronik menggunakan aplikasi ORIGEN dan MCNP. Massa ${ }^{235} \mathrm{U}$ di dalam bahan bakar $\mathrm{U}_{3} \mathrm{O}_{8} / \mathrm{Al}$ untuk setiap PEB sebanyak $11,90^{ \pm 0,3}$ gram. Massa ini merupakan standar dalam fabrikasi bahan bakar $\mathrm{U}_{3} \mathrm{O}_{8} / \mathrm{Al}$ untuk mendapatkan densitas uranium sebesar 2,96 $\mathrm{gU} / \mathrm{cm}^{3}$ sesuai standar bahan bakar RSG-GAS. Hasil perhitungan massa ${ }^{235} \mathrm{U}$ dan ${ }^{238} \mathrm{U}$ di dalam bahan bakar $\mathrm{U}_{3} \mathrm{Si}_{2} / \mathrm{Al}$ maupun jenis $\mathrm{U}$ $7 \mathrm{Mo} / \mathrm{Al}$ dengan densitas uranium berturutturut 4,8 dan $7,0 \quad \mathrm{gU} / \mathrm{cm}^{3}$ dengan menggunakan metode dan cara yang sama ditunjukkan pada Tabel 1. 
Massa ${ }^{235} U$ dan ${ }^{238} U$ yang ditunjukkan pada Tabel 1 digunakan sebagai bahan simulasi iradiasi menggunakan aplikasi ORIGEN. Hasil simulasi diperoleh berupa massa produk-produk fissi dan massa uranium di dalam bahan bakar nuklir sisa $\left({ }^{235} \mathrm{U}\right.$ yang tidak mengalami reaksi fisil). Massa bahan bakar nuklir sisa inilah yang digunakan sebagai data perhitungan burn up. Hasil perhitungan burn up dengan dari massa ${ }^{235} \mathrm{U}$ sisa menggunakan aplikasi ORIGEN ditunjukkan pada Tabel 2.

Tabel 2. Burn up hasil perhitungan menggunakan ORIGEN

\begin{tabular}{|c|c|c|c|c|c|}
\hline $\begin{array}{l}\text { Bahan } \\
\text { bakar }\end{array}$ & $\begin{array}{l}\text { Densitas } \\
\text { uranium } \\
\left(\mathrm{gU} / \mathrm{cm}^{3}\right)\end{array}$ & $\begin{array}{l}\text { Lama iradiasi } \\
\text { (hari) }\end{array}$ & $\begin{array}{c}\text { Massa }{ }^{235} \mathrm{U} \text { sisa } \\
(\mathrm{g})\end{array}$ & $\begin{array}{c}\text { Burn up } \\
(\%)\end{array}$ & $\begin{array}{c}\text { Burn up / EB } \\
\text { (MWD) }\end{array}$ \\
\hline \multirow{6}{*}{$\mathrm{U}_{3} \mathrm{O}_{8} / \mathrm{Al}$} & \multirow{6}{*}{2,96} & 22 & 232,10 & 7,08 & 14,52 \\
\hline & & 44 & 214,50 & 14,13 & 29,04 \\
\hline & & 66 & 197,20 & 21,06 & 43,56 \\
\hline & & 136 & 144,70 & 42,07 & 89,76 \\
\hline & & 162 & 126,80 & 49,24 & 106,92 \\
\hline & & 188 & 109,90 & 56,00 & 124,08 \\
\hline \multirow{7}{*}{$\mathrm{U}_{3} \mathrm{Si}_{2} / \mathrm{Al}$} & \multirow{7}{*}{4,80} & 32 & 359,80 & 6,68 & 21,12 \\
\hline & & 104 & 302,70 & 21,49 & 68,64 \\
\hline & & 136 & 278,00 & 27,89 & 89,76 \\
\hline & & 172 & 250,90 & 34,92 & 113,52 \\
\hline & & 292 & 168,50 & 56,30 & 192,72 \\
\hline & & 352 & 133,20 & 65,45 & 232,32 \\
\hline & & 384 & 116,30 & 69,83 & 253,44 \\
\hline \multirow{6}{*}{ U-7Mo/Al } & \multirow{6}{*}{7,00} & 49 & 522,90 & 7,00 & 32,34 \\
\hline & & 147 & 445,10 & 20,84 & 97,02 \\
\hline & & 252 & 365,00 & 35,08 & 166,32 \\
\hline & & 420 & 249,40 & 55,64 & 277,20 \\
\hline & & 567 & 166,1 & 70,46 & 374,22 \\
\hline & & 651 & 127,2 & 77,38 & 429,66 \\
\hline
\end{tabular}

Tabel 2 menunjukkan bahan bakar $\mathrm{U}_{3} \mathrm{O}_{8} / \mathrm{Al}$ dengan densitas $2,96 \mathrm{gU} / \mathrm{cm}^{3}$ memiliki burn up yang mendekati dengan burn up operasional yaitu sebesar 652,54 $M W D^{[8]}$. Besaran burn up ini diperoleh dari perhitungan 22 hari/7,08 \% × $7 \% \times 30 \mathrm{MW}$ $=652,54 \mathrm{MWD}$ ( dimana 7,08 \% adalah burn up hasil simulasi, $7 \%$ adalah besar deviasi dan $30 \mathrm{MW}$ adalah daya maksimal operasi reaktor). Hasil perhitungan burn up dan lamanya waktu iradiasi sebesar 188 hari untuk bahan bakar $\mathrm{U}_{3} \mathrm{O}_{8} / \mathrm{Al}$ menggunakan aplikasi ORIGEN diperoleh cukup akurat sehingga besaran ini dapat digunakan sebagai acuan.
Dari Tabel 2 diketahui bahwa untuk mencapai burn up sebesar $56 \%$ pada bahan bakar $\mathrm{U}_{3} \mathrm{O}_{8} / \mathrm{Al}, \quad \mathrm{U}_{3} \mathrm{Si}_{2} / \mathrm{Al}$, dan $\mathrm{U}-7 \mathrm{Mo} / \mathrm{Al}$ memerlukan lama iradiasi sebesar 188 hari, 292 hari, dan 420 hari. Hal ini menunjukkan bahwa terjadi peningkatan umur bahan bakar (life time) dengan burn up yang sama.

Data burn up yang diperoleh dari perhitungan aplikasi ORIGEN, selanjutnya digunakan sebagai input untuk perhitungank $_{\text {eff }}$ pada aplikasi MCNP. Hasil perhitungan $k_{\text {eff }}$ menggunakan MCNP ditunjukkan pada Gambar 6. 


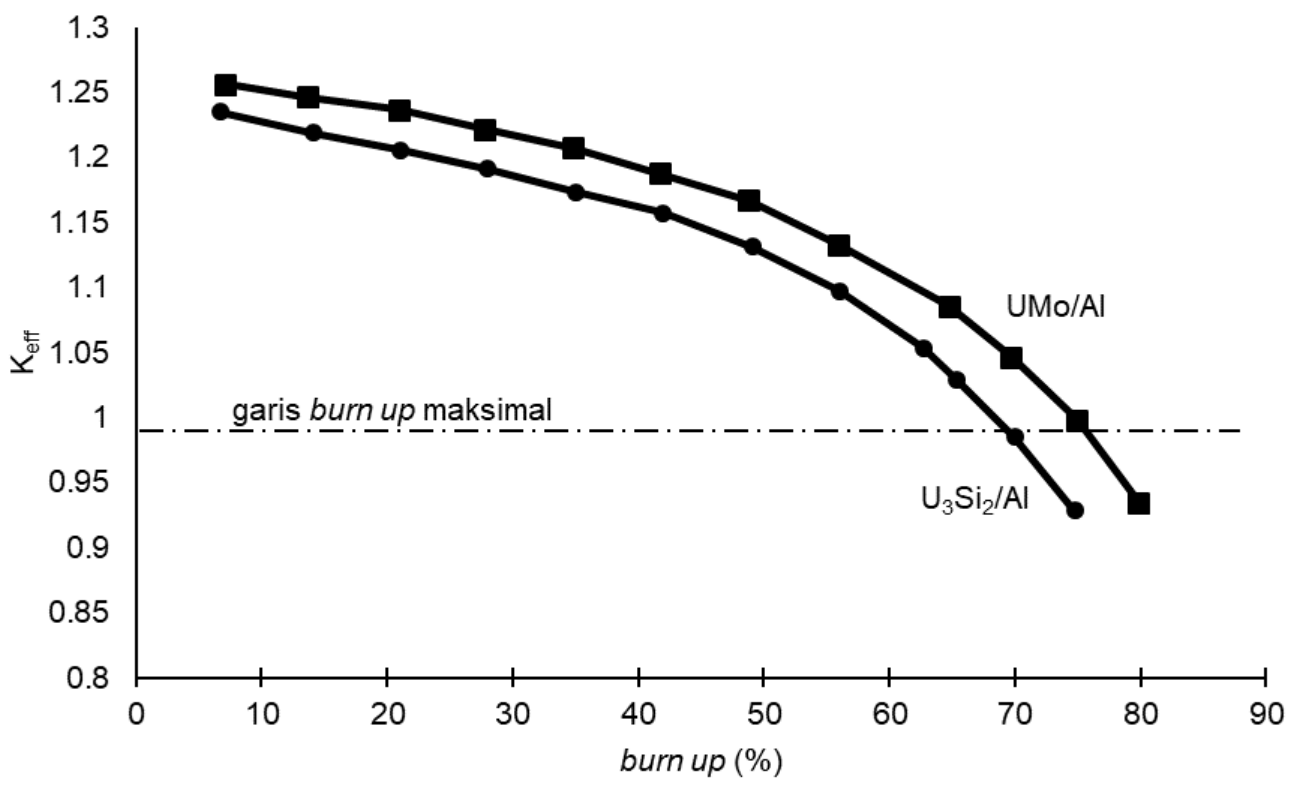

Gambar 6. Grafik perhitungan $\mathrm{k}_{\text {eff }}$ menggunakan MCNP

Gambar 6 menunjukkan bahwa garis horizontal merupakan nilai acuan $\mathrm{k}_{\text {eff }}$ sebesar 0,99613 yang diperoleh dari perhitungan bahan bakar $\mathrm{U}_{3} \mathrm{O}_{8} / \mathrm{Al}$ pada burn up $56 \%$ menggunakan MCNP. Pada Gambar 6 terlihat bahwa garis acuan $\left(k_{\text {eff }}=0,99613\right)$ memotong dua garis lainnya, perpotongan antara garis acuan dengan garis lainnya merupakan perkiraan burn up maksimal yang dapat dicapai dari bahan bakar $\mathrm{U}_{3} \mathrm{Si}_{2} / \mathrm{Al}$ dan U7Mo/Al.

Gambar 6 menunjukkan bahwa perhitungan menggunakan persamaan regresi linear antara dua titik yang berdekatan dengan garis perpotongan diperoleh burn up maksimal. Dari perpotongan garis tersebut diperoleh nilai burn up untuk bahan bakar $\mathrm{U}_{3} \mathrm{Si}_{2} / \mathrm{Al}$ dan $\mathrm{U}-7 \mathrm{Mo} / \mathrm{Al}$ masing masing sebesar $69,83 \%$ dan $77,38 \%$. Besaran burn up ini berkorelasi dengan umur bahan bakar $\mathrm{U}_{3} \mathrm{Si}_{2} / \mathrm{Al}$ dan $\mathrm{U}-7 \mathrm{Mo} / \mathrm{Al}$ yaitu sebesar 384 hari dan 651 hari seperti yang ditunjukkan pada Tabel 2. Peningkatan densitas uranium di dalam bahan bakar mengakibatkan burn up dan umur bahan bakar di dalam reaktor meningkat cukup signifikan.

Dari besar burn up yang diperoleh untuk ketiga jenis bahan bakar yaitu
$\mathrm{U}_{3} \mathrm{O}_{8} / \mathrm{Al} ; \quad \mathrm{U}_{3} \mathrm{Si}_{2} / \mathrm{Al}$, dan U-7Mo/Al yaitu masing masing sebesar $56 \%$, sebesar $69,83 \%$ dan $77,38 \%$, dapat ditentukan besar isotop ${ }^{235} \mathrm{U}$ sisa. Hasil perhitungan menunjukkan bahwa besar isotop ${ }^{235} \mathrm{U}$ sisa pada bahan bakar $\mathrm{U}_{3} \mathrm{O}_{8} / \mathrm{Al}, \mathrm{U}_{3} \mathrm{Si}_{2} / \mathrm{Al}$, dan $\mathrm{U}-7 \mathrm{Mo} / \mathrm{Al}$ masing-masing diperoleh sebesar $109,90 \mathrm{~g} ; 116,30 \mathrm{~g}$ dan $127,2 \mathrm{~g}$. Nilai tersebut adalah nilai kompensasi terhadap unsur-unsur penyerap neutron, terutama ${ }^{238} \mathrm{U}$ yang jumlah unsurnya paling banyak. Bila pembakaran massa ${ }^{235} \mathrm{U}$ melebihi dari nilai tersebut akan menyebabkan reaktor menjadi sub kritis $\left(k_{\text {eff }}<1\right)$ dan proses reaksi fisi di dalam reaktor akan berhenti. Bahan bakar UMo/Al mempunyai massa isotop ${ }^{235} \mathrm{U}$ sisa tertinggi karena densitas uraniumnya paling tinggi, sehingga massa isotop ${ }^{238} \mathrm{U}$ di dalam bahan bakar juga paling banyak.

\section{SIMPULAN}

Peningkatan densitas uranium dalam bahan bakar berdampak kepada bertambahnya waktu iradiasi di dalam reaktor dan burn up bahan bakar. Waktu iradiasi yang dibutuhkan untuk mencapai burn up sebesar $56 \%$ masing masing bahan bakar $\mathrm{U}_{3} \mathrm{O}_{8} / \mathrm{Al} ; \quad \mathrm{U}_{3} \mathrm{Si}_{2} / \mathrm{Al}$, dan U-7Mo/Al selama 188 hari, 292 hari, dan 420 hari. 
Peningkatan densitas uranium dalam bahan bakar menyebabkan bahan bakar $\mathrm{U}_{3} \mathrm{O}_{8} / \mathrm{Al}$ mampu mencapai burn up $56 \%$, sedangkan $\mathrm{U}_{3} \mathrm{Si}_{2} / \mathrm{Al}$ dan U-7Mo/Al dapat mencapai burn up sebesar 68,97 \% dan 76,76 \%. Meningkatnya waktu iradiasi atau umur (lifetime) dan burn up bahan bakar berdampak kepada meningkatkan efisiensi bahan bakar. Hasil pemodelan ini khususnya umur dan burn up bahan bakar dapat sebagai masukan untuk melakukan iradiasi $\mathrm{U}_{3} \mathrm{Si}_{2} / \mathrm{Al}$ dan U-7Mo/Al dalam RSGGAS.

\section{DAFTAR PUSTAKA}

[1] T. Wang et al., "First-principles investigations on the electronic structures of $\mathrm{U}_{3} \mathrm{Si}_{2}$ ", Journal of Nuclear Materials, vol. 469, pp. 194 199, 2016.

[2] S. Van den Berghe, A. Leenaers, E. Koonen, L. Sannen, "From high to low enriched uranium fuel in research reactors", Advances in Science and Technology, vol. 73, pp. 78-90, 2010.

[3] I. Kuntoro, T. M. Sembiring, "Desain reras alternatif untuk reaktor riset inovatif (RRI) dari aspek neutronik", Jurnal Teknologi Reaktor Nuklir, vol. 16, no. 1, hal. 1-10, 2014.

[4] A. M. Saliba-Silva, E. F. U. de Carvalho, H. G. Riella, and M. Durazzo, "Radioisotopes-Applications in Physical Sciences". InTech, 2011.

[5] Supardjo, "Stabilitas fasa dan karakteristik difusi bahan bakar dispersi U-Mo-X(X=Si, Ti, Zr) Pada proses fabrikasi/iradiasi”, Prosiding Nasional XX Kimia Dalam Industri dan Lingkungan, Yogjakarta, 2011.

[6] Supardjo, A. Kadarjono, Boybul, A. B. Ginting, "Pengaruh unsur Zr terhadap perubahan sifat termal bahan bakar dispersi U-7Mo-xZr/Al", Urania, vol. 22, no. 1, hal 13-24, 2016.

[7] Supardjo, A. Kadarjono, M. Kartaman, Boybul, "Pengaruh densitas uranium pada proses pembuatan pelat elemen bakar dispersi U-7Mo/Al dan U-7Mo/Al-Si", Urania, vol. 18, no. 3, hal. 150-162, 2012.

[8] M. Imron and A. Sunardi, "Perhitungan burn up bahan bakar reaktor RSG-GAS menggunakan paket program BATAN-FUEL", Prosiding Seminar Nasional Teknologi dan Aplikasi Reaktor Nuklir PRSG, 2012, hal. 45-50.

[9] L. Suparlina, "Manajemen konversi Teras RSG-GAS berbahan bakar silisida tingkat muat tinggi", Jurnal Teknologi Reaktor Nuklir, vol. 15, no. 3, hal. 137-149, 2013.

[10] L. Suparlina and T. Surbakti, "Analisis pola manajemen bahan bakar teras reaktor riset tipe MTR, Jurnal Teknologi Reaktor Nuklir, vol. 16, no. 2, pp. 89-99, 2014.

[11] Croff.A.G, "A User 's Manual for the ORIGEN Computer Code", Tennessee, 1980.

[12] M. A. Shafii, "Solution methods of neutron transport equation in nuclear reactors", Jurnal Ilmu Dasar, vol. 14, no. 2, hal. 59, 2013.

[13] L. Peng Hong and T. M. Sembiring, "Development of new ORIGEN2 data library sets for research reactors with light water cooled oxide and silicide LEU (20 w/o) fuels based on JENDL3.3 nuclear data", Nuclear Engineering and Design, vol. 262, pp. 52-62, 2013. 